\title{
Chemotherapeutic effects on larval stages of Schistosoma mansoni during infection and re-infection of mice
}

\author{
Efeitos da quimioterapia nos estágios larvais do Schistosoma mansoni \\ durante infecção e re-infecção de camundongos
}

\author{
Luciana M. Silva', Rejane M. C. Menezes ${ }^{1}$, Sheilla Andrade de Oliveira² and Zilton A. Andrade ${ }^{1}$
}

\begin{abstract}
The sensitivity of the larval stages of Schistosoma mansoni to chemotherapy with praziquantel and oxamniquine was tested in mice during primary and secondary infections and after different intervals from cercarial exposure. Worm recovery by perfusion of the porto-mesenteric system, followed by counting and a morphometric study of the parasite, allowed the conclusion that the relative resistance of the larval stages of $S$. mansoni to schistosomicide drugs, demonstrated in primary infections, also persists when the host is already infected. This indicates that a therapeutic failure may result when an infected host is treated some time after being re-infected, because of the presence of migrating, drug-resistant, immature forms of the parasite.
\end{abstract}

Key-words: Schistosoma mansoni. Larval stages. Praziquantel. Oxamniquine.

Resumo $A$ susceptibilidade dos estágios larvais do Schistosoma mansoni aos esquistossomicidas praziquantel e oxamniquine foi testada em camundongos durante infecção primária ou secundária, e após diferentes intervalos de tempo após a exposição cercariana. A avaliação foi feita pela contagem dos vermes após recuperação destes por perfusão do sistema porto-mesentérico e pelo estudo morfométrico dos mesmos. O estudo revelou que a relativa resistência das formas larvais aos esquistossomicidas, já demonstrada em infecção primária, persiste no caso de hospedeiros já infectados. Este fato indica que uma falha terapêutica pode resultar quando o tratamento é feito em hospedeiros re-infectados recentemente, em virtude dos mesmos apresentarem formas migrantes e imaturas do parasita, as quais são particularmente resistentes aos esquistossomicidas.

Palavras-chaves: Schistosoma mansoni. Estágio Larval. Praziquantel. Oxamniquine.

Oxamniquine and praziquantel are the two drugs used in Brazil for the treatment of schistosomiasis. Large scale treatment programs using either drug have been carried out in several Brazilian endemic areas ${ }^{10} 11^{13}$. Treatment efficacy is considered satisfactory, but failures have been registered with variable frequency. Such therapeutic failures are often attributed to the development of drug resistance by the worms and to early post treatment re-infection 267 . However, in areas of high transmission, another possibility may occur. Treated individuals, even though apparently cured, may re-establish the infection in consequence of the existence of migrating larval forms of Schistosoma mansoni, which are usually resistant to chemotherapy, as experimentally demonstrated ${ }^{1621}$.
Sabath et $\mathrm{al}^{16}$ have shown that schistosomula are far less susceptible than adult worms to six schistosomicides at curative doses, including praziquantel and oxamniquine. However, these studies were performed in mice with experimental primary infections treated at different points of time after cercarial exposure. Since the effect of chemotherapy is influenced by the immune state of the host $^{3415}$, the response of the larval stages of $S$. mansoni to schistosomicides should also be tested during reinfection.

The present investigation studied the effects of oxamniquine or praziquantel on different larval stages of $S$. mansoni in mice with primary infection compared to mice submitted to re-infection.

\footnotetext{
1. Laboratório de Patologia Experimental do Centro de Pesquisas Gonçalo Moniz da Fundação Oswaldo Cruz, Salvador, BA, Brazil. 2. Laboratório de Imunopatologia do Centro de Pesquisas Aggeu Magalhães da Fundação Oswaldo Cruz, Recife, PE, Brasil.

Financial support: PRONEX

Address to: Dr. Zilton Andrade. Rua Waldemar Falcão 121 Brotas, 40295-001 Salvador, BA, Brasil.

e-mail:zilton@cpqgm.fiocruz.br

Recebido para publicação em 27/7/2002

Aceito em 26/2/2003
} 


\section{MATERIAL AND METHODS}

Two main experiments were performed. The first experiment involved 185 outbred Swiss mice of both sexes, weighing 18-22g, that were infected transcutaneously with $100 \mathrm{~S}$. mansoni cercariae of the Feira de Santana strain ${ }^{1}$. This strain has been maintained through successive passages in laboratoryraised Bimphalaria glabrata. The infected animals were randomly separated into three groups:

Group 1: consisted of 25 mice that were not subjected to drug treatment, and served as untreated controls. Animals were sacrificed 40 days after cercarial exposure, when the worms were recovered from the portalmesenteric venous system by perfusion, according to Duvall and DeWitt ${ }^{8}$.

Group 2: included 80 mice treated with oxamniquine. The drug was suspended in distilled water and administered by gavage in a single dose of $100 \mathrm{mg} / \mathrm{kg} /$ bw. at $5,10,20$ or 30 days following infection, 20 different animals being treated at each time point. Thirty days after treatment (35-60 days after infection), the animals were anesthetized and sacrificed by severing the abdominal aorta. Worms were recovered by perfusion of the portal system.

Group 3: also with 80 mice, received praziquantel, administered by gavage in a dose of $400 \mathrm{mg} / \mathrm{kg} / \mathrm{w}$, otherwise following the same steps as for the previous Group. Another approach was made with 153 Swiss mice, which were at first submitted to transcutaneous infection with $30 \mathrm{~S}$. mansoni cercariae. Thirty to fortyfive days afterwards, the animals were exposed to reinfection with 50 cercariae. Only mice passing viable eggs in the stools were used. Similarly to the first experiment, re-infected animals were separated into three groups, as follows: a) untreated re-infected controls $(\mathrm{n}=13) ; \mathrm{b})$ treated with oxamniquine $(100 \mathrm{mg} / \mathrm{kg}, \mathrm{n}=$ $64)$; and c) treated with praziquantel $(400 \mathrm{mg} / \mathrm{kg}, \mathrm{n}=$
64). Chemotherapies were administered by gavage one time only, 10, 20 or 30 days following re-infection, for sub-groups of animals, according to the intervals after re-infection. Twenty days after treatment, re-infected animals were anesthetized and sacrificed for recovery of worms. Untreated controls were sacrificed 30 days after re-infection.

An additional group was also included in this experiment, consisting of an extra non-treated control group with primary infection for comparing the effect of the cumulative infections ( $n=12,30$ cercariae).

Drug efficacy was determined through the percentage of worm load reduction, by using the formula by Sabah et $\mathrm{al}^{15}\left(R^{*}=100-(\mathrm{t} \times 100 / \mathrm{c})\right.$, where $t=$ median of worms recovered from the treatment group and $c=$ median of worms recovered from the untreated group, and comparing treated and non-treated animals in their respective groups and sub-groups. Median numbers of worms were compared by means of the Mann Whitney test.

In an attempt to separate the young and old worms from infections made at different times, a morphometric analysis was performed. Male and female worms were recovered from mice with one single infection, and from those infected and re-infected, including treated and non-treated controls. The worms were fixed in neutral $10 \%$ formalin, stained with carmine chloride, dehydrated in alcohol, cleared in creosote and mounted on glass slides with a 1:1 mixture of Canadian balsam and creosote for microscopic examination. Considering sexual dimorphism, morphometric evaluation was made separately for male and female worms. A Leica Quantimet 500C (Leica Cambridge, U.K.) system, with a Sigma-Scan Measurement semi automatic morphometric device (Jandel Scientific, SF, USA) was used. The variables considered were: corporeal length; number of testicular masses; and the presence of eggs in uterus.

\section{RESULTS}

The first experiment revealed that the sensitivity of S. mansoni larvae to both oxamniquine and praziquantel varied according to their developmental stage. Oxamniquine yielded poor results during the first 20 days of infection, the percentage reduction of worm-load was $28-34 \%$ in treated as compared to non-treated mice (Table 1). However, 30 days after exposure, the percentage reduction was 86 to $100 \%$, which was statistically significant when compared to pre-treatment. The $p$ value varied from 0.001 to $<0.0001$. For the other periods the effect of chemotherapy was the same. Regarding praziquantel, efficacy was 48 to $52 \%$ for the animals treated until 10 days after cercarial exposure, dropping to $19 \%$ on the $30^{\text {th }}$ day. For the two first experimental points, praziquantel did not improve the efficacy in further reducing worm load $(p=0.9440)$. However, between the $10^{\text {th }}$ to $30^{\text {th }}$ days, reduction in worm load was significant. Compared to oxamniquine, the efficacy of praziquantel did not essentially differ on the $10^{\text {th }}$ day period $(p=0.07)$, although the latter seemed more effective on the $20^{\text {th }}$ day of infection $(p<0.0001)$, while better effects occurred with the former by the $30^{\text {th }}$ day, $p<0.0001$. (Table 1).

During the second experiment the percentage reduction of worm load was greater for both treatment groups when compared to the re-infected controls. (Figures 1b, c, d, e, f and g; and Table 2). Oxamniquine was seen to be very effective by the $10^{\text {th }}$ day following re-infection, presenting a reduction of $64 \%$. These figures decreased subsequently by the $20^{\text {th }}$ day post infection ( $p=0.0409)$, while still varying with time, a few mice were totally cured among those treated later on. Thus, no variation in the chemotherapy action was demonstrated between 20 and 30 days following cercarial exposure $(p=0.1031)$. In fact, praziquantel 
Table 1 - Mice exposed to 100 Schistosoma mansoni cercariae and treated with either oxamniquine or praziquantel after different periods of pre-patent infection.

\begin{tabular}{lcccccc}
\hline Groups & $\begin{array}{c}\text { No. of animals } \\
\text { per group }\end{array}$ & $\begin{array}{c}\text { Day of treatment following } \\
\text { cercarial exposure }\end{array}$ & $\begin{array}{c}\text { Mean no. of } \\
\text { worms recovered }\end{array}$ & Variation & $\% \mathrm{R}^{*}$ & $p$ \\
\hline Untreated controls & 22 & 0 & 26.7 & $14-52$ & - & - \\
\hline Oxamniquine & 20 & 5 & 18.0 & $6-30$ & 33.0 & 0.0004 \\
& 20 & 10 & 19.4 & $1-39$ & 28.0 & $<0.014$ \\
& 18 & 20 & 17.8 & $3-37$ & 34.0 & 0.0016 \\
& 20 & 30 & 3.6 & $0-13$ & 86.0 & $<0.0001$ \\
\hline Praziquantel & 19 & 5 & 14.0 & $6-43$ & 48.0 & $<0.0001$ \\
& 20 & 10 & 13.5 & $2-30$ & 52.0 & $<0.0001$ \\
& 20 & 20 & 5.4 & $0-18$ & 80.0 & $<0.0001$ \\
& 20 & 30 & 21.9 & $1-40$ & 19.0 & 0.08 \\
\hline
\end{tabular}

$\mathrm{R}^{*}$ Percent of worm-load reduction.

Table 2 - Mice exposed to 30 Schistosoma mansoni cercariae, re-infected with 50 cercariae, and then treated with either oxamniquine or praziquantel after different periods of pre-patent re-infection.

\begin{tabular}{|c|c|c|c|c|c|c|}
\hline Groups & $\begin{array}{c}\text { Day of treatment } \\
\text { followingre-infection }\end{array}$ & $\begin{array}{c}\text { No. of animals } \\
\text { per group }\end{array}$ & Mean number of worms & Variation & $\% \mathrm{R}^{*}$ & $p$ \\
\hline Controllnfection with 30c & - & 12 & 12.2 & $3-26$ & - & - \\
\hline Re-infection & - & 13 & 20.6 & $10-31$ & - & - \\
\hline \multirow[t]{3}{*}{ Oxamniquine } & 10 & 23 & 7.4 & $0-16$ & 64.0 & 0.005 \\
\hline & 20 & 21 & 14 & $0-41$ & 32.0 & 0.03 \\
\hline & 30 & 20 & 9.0 & $0-27$ & 57.0 & 0.035 \\
\hline \multirow[t]{3}{*}{ Praziquantel } & 10 & 19 & 6.0 & $0-16$ & 76.0 & 0.027 \\
\hline & 20 & 22 & 7.7 & $0-18$ & 74.0 & 0.034 \\
\hline & 30 & 23 & 5.4 & $0-16$ & 76.0 & 0.004 \\
\hline
\end{tabular}

$\mathrm{R}^{*}$ Percent of worm-load reduction.

reduction of worm-load for the animals re-infected and treated reached $75 \%$. Praziquantel was more effective than oxamniquine in reducing worm load during re-infection, although not at a statistically significant level. A $76 \%$ reduction occurred when treatment was given at the $10^{\text {th }}$, $20^{\text {th }}(74 \%)$ and $30^{\text {th }}$ day following re-infection $(76 \%)$. All animals treated after re-infection showed statistically significant differences in worm-load reduction when compared with the re-infected but untreated control group.

The mean male worm length for the control group of single infection was $7,958 \times 10^{-3} \mathrm{~mm}$, with a confidence interval between $7,644.5$ and $8,272.2 \times 10^{-3}$. The figures for females were: $10,457.4 \times 10^{-3}$ with confidence interval of $9,536.1$ to $11,378.7 \times 10^{-3}$. To evaluate worm length from a second infection, the values obtained were distributed in quartiles. In quartile 25 it was noted that the length of male and female worms was $6,300 \times 10^{-3}$ and $7,356 \times 10^{-3}$, respectively. It was considered that worms of both sex with body length equal or inferior to these figures represented worms from the second infection. Figure 2 is based on such data.

\section{DISCUSSION}

The present study shows that the effect of the schistosomicide drugs, praziquantel and oxamniquine, upon migrating schistosomula in mice differs according to the drug used and the time of infection. Furthermore, several authors have reported that the larval stages of S. mansoni are less susceptible to chemotherapy than young and adult worms ${ }^{31621}$. These differences were now seen to be accentuated when the treatment was made after several different periods following re-infection.

It has been demonstrated that the drug-induced killing of adult worms is mediated by the host immune system ${ }^{3415}$. The schistosomicides administered cause focal areas of damage to the worm tegument ${ }^{12}{ }^{18}$, exposing target antigens to host antibodies, which ultimately provoke the worm death ${ }^{3917}$. Unfortunately, the role played by the immune system cannot be enhanced by means of artificial antigenic stimulation ${ }^{19}$.

There are few and contradictory experimental data concerning the participation of the immune response during the drug killing of immature schistosomes. Studies made with immunofluorescence labeling after recovering of lung-stage larvae, soon after treatment with praziquantel, revealed mild tegumental lesions with exposure of parasite antigens ${ }^{9}$. However, transfer of the immune serum from 6 to 7 -week-old infections to intact mice carrying 25-day-old schistosome infections did not enhance praziquantel chemotherapy of these infections ${ }^{3}$.

Some reduction in worm load in re-infected animals is to be expected since infected mice are not only immunologically protected from a new cercarial 


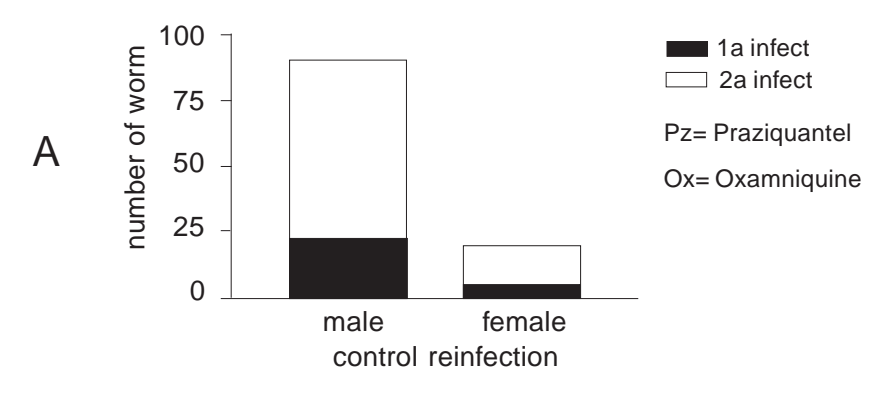

B
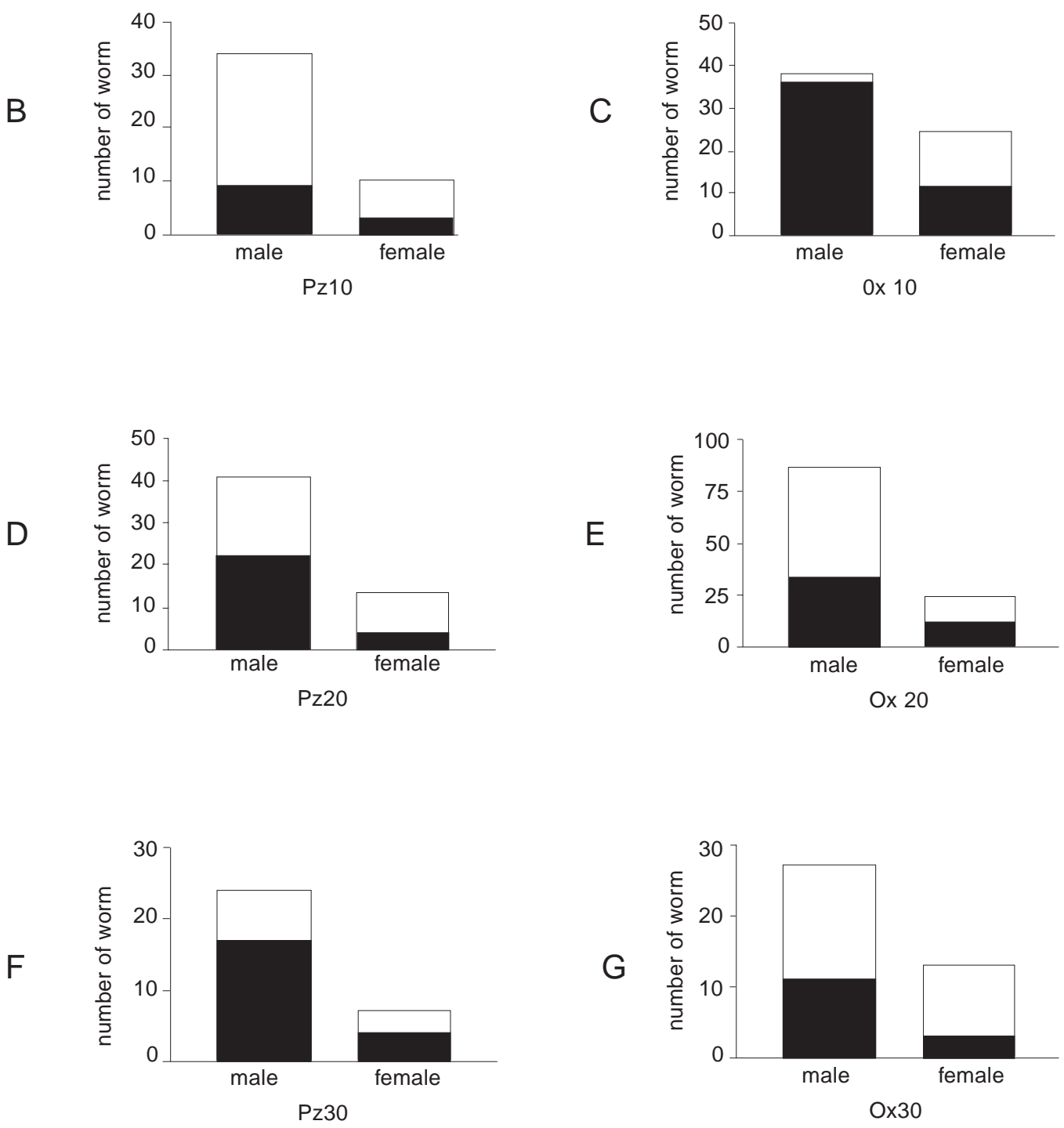

Figure 1 - Worms recovered (males and females) after single infection and re-infection with Schistosoma mansoni and following treatment with either praziquantel or oxamniquine at different periods after re-infection. 

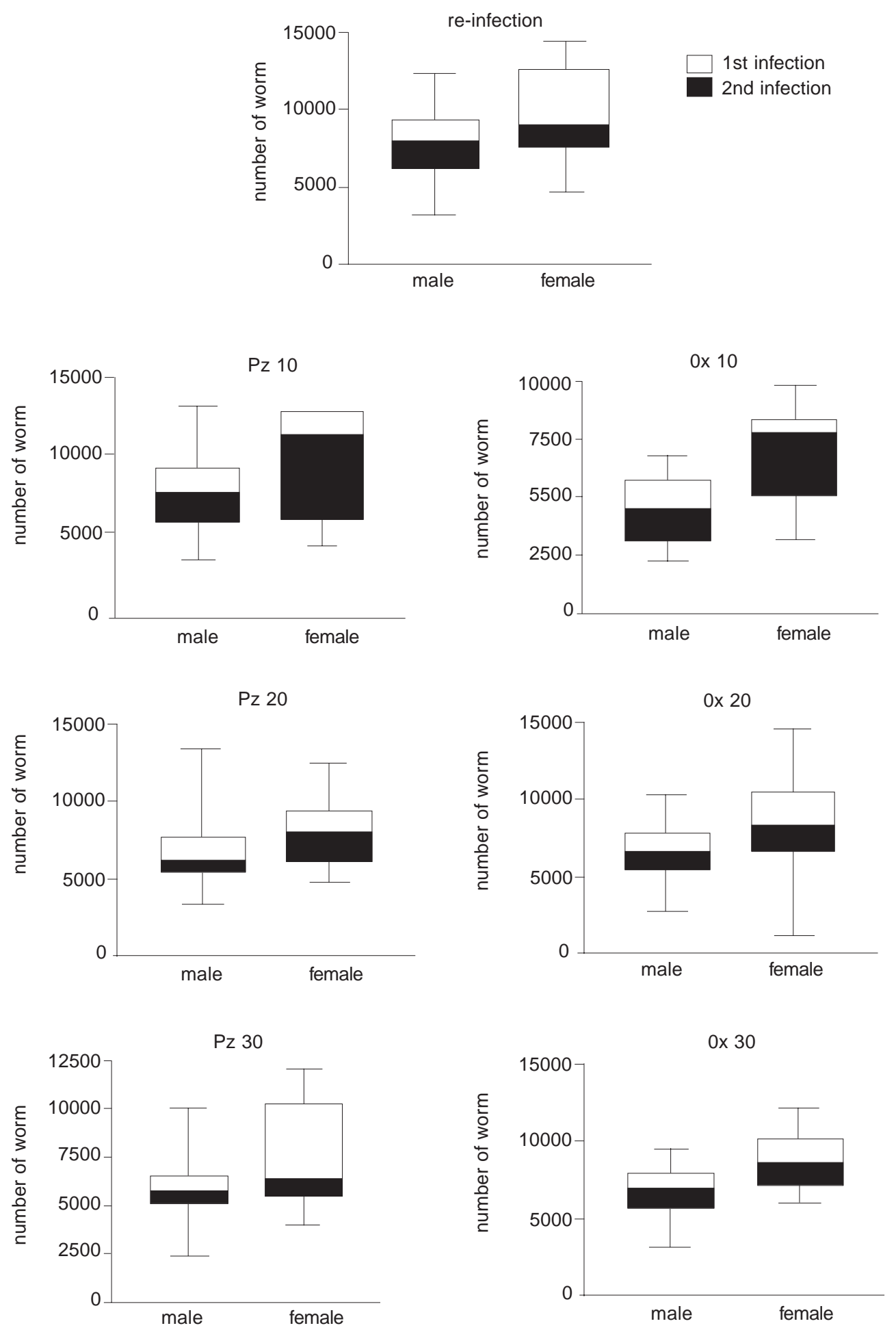

Figure 2 - Length $(\mathrm{mm})$ of recovered Schistosoma mansoni after treatment with praziquantel $(\mathrm{Pz})$ or oxamniquine $(0 x)$, at 10, 20 and 30 days following re-infection of mice. 
infection ${ }^{5}$, but also by other non-immunological factors. Some studies have demonstrated that the migrating schistosomula of a re-infection can be diverted into portal collateral vessels toward peripheral tissues, where they may die as a result of being out of their natural habitat ${ }^{1420}$. However, although these factors are important, they alone do not explain the present results.

A significant worm load reduction occurred after treatment in all treated and re-infected groups. In addition, there were also marked differences in relation to the period after re-infection when the treatment was made. In this regard, the $64 \%$ reduction in worm load observed with oxamniquine treatment starting on day 10 after re-infection, can be confronted with that of $28 \%$ in controls with single infections. This latter result also contrasts with the general observation, derived from the treatment of single infections, which revealed that the more immature the schistosomula, the more resistant they are to schistosomicides.

In animals exposed to a second infection, praziquantel exhibited greater homogeneity of positive results, with a percentage of worm reduction in the order of $75 \%$, in comparison to the 32 to $64 \%$ obtained with oxamniquine (Table 1). The number of testicular masses evaluated in the different groups, did not show significant differences in regard to re-infection or treatment, although oxamniquine revealed a greater reduction in egg production.

In spite of the observation that schistosomicide drugs were effective against migrating $S$. mansoni larvae during re-infection, the effect was always partial.

Therefore, these data support the possibility that a therapeutic failure may be due to the presence of migrating forms of $S$. mansoni, which escaped being killed by drugs within the organism of a treated individual.

\section{ACKNOWLEDGEMENT}

Thanks are due to Mr. Brendan L. Flannery (University of California, Berkeley, CA, USA) for revision of the English text and help with the preparation of tables and figures, to Mr Antonio Carlos da Silva Santos, for technical assistance, and to Mr. Ulisses Ramos Montarroyos (Centro de Pesquisas Aggeu Magalhães (FIOCRUZ), Recife, PE, Brazil) for statistical analysis of morphometric data.

\section{REFERENCES}

1. Andrade ZA, Sadigursky M. Um estudo comparativo das cepas Feira de Santana (Bahia) e Porto Rico do Schistosoma mansoni na infecção experimental do camundongo. Memórias do Instituto Oswaldo Cruz 80:37-40, 1985.

2. Araújo N, Souza CP, Passos LKJ, Simpson AJG, Dias Neto E, Pereira TR, Curutti Jr C, Alencar FEC, Dietze R, Katz N. Susceptibilidade aos agentes quimioterápicos de isolados de Schistosoma mansoni oriundos de pacientes tratados com oxamniquine e praziquantel e não curados. Revista da Sociedade Brasileira de Medicina Tropical 29:467-476, 1996

3. Brindley PJ. Relationship between chemotherapy and immunity in schistosomiasis. Advances in Parasitology 34:133-161, 1994.

4. Brindley PJ, Sher A. The chemotherapeutic effect of praziquantel against Schistosoma mansoni is dependent on host antibody response. The Journal of Immunology 139:215-220, 1987.

5. Coelho PMZ, Mello RT, Pollom TEV. Schistosoma mansoni: Reinfections and concomitant immunity in mice. Importance of perfusion time after challenge infection for evaluation of immunoprotection. Memórias do Instituto Oswaldo Cruz 90:507509, 1995.

6. Conceição MJ, Agento CA, Correa A. Study of Schistosoma mansoni isolates from patients with failure of treatment with oxamniquine. Memórias do Instituto Oswaldo Cruz 95: 375-380, 2000.

7. Costa MFFL, Katz N, Dias JCP. Reinfecção de pacientes em áreas endêmicas de esquistossomose mansoni após tratamento específico. Revista do Instituto de Medicina Tropical de São Paulo 22:97-107, 1980.

8. Duvall RH, DeWitt WB. An improved perfusion technique for recovering adult schistosomes from laboratory animals. The American Journal of Tropical Medicine and Hygiene 16:483-486, 1967.
9. Flisser A, McLaren DJ. Effect of praziquantel treatment on lungstage larvae of Schistosoma mansoni in vivo. Parasitology 98:203211, 1989.

10. Katz N. Experiência com quimioterapia em grande escala no controle da esquistossomose no Brasil. Revista do Instituto de Medicina Tropical de São Paulo 22:40-51, 1980.

11. Kloetzel K, Schuster NH. Repeated mass treatment of schistosomiasis mansoni: experience in hyperendemic area of Brazil. I. Parasitological effects and morbidity. Transactions of the Royal Society of Tropical Medicine and Hygiene 81:365-370, 1987.

12. Kohn A, Serapião CJ, Katz N, Dias EP. Ação da oxamniquine sobre - Schistosoma mansoni em camundongos experimentalmente infectados. Revista do Instituto de Medicina Tropical de São Paulo 21:217-227, 1979.

13. Machado PA. The Brazilian program for schistosomiasis control, 1975-1979. The American Journal of Tropical Medicine and Hygiene 31:76-86, 1982.

14. Medeiros MVMJ, Andrade ZA. The importance of collateral portal veins for resistance to schistosomiasis in mice. Brazilian Journal of Medical and Biological Research 19:85-88, 1986.

15. Sabah AA, Fletcher C, Webbe G, Doenhoff MJ. Schistosoma mansoni: Reduced efficacy of chemotherapy in infected T-celldeprived mice. Experimental Parasitology 60:348-354, 1985.

16. Sabah AA, Fletcher C, Webbe G, Doenhoff MJ. Schistosoma mansoni: Chemotherapy of infections of different ages. Experimental Parasitology 61:294-303, 1986.

17. Shaw MK. Schistosoma mansoni: stage-dependent damage after in vitro treatment with praziquantel. Parasitology 100:65-72,1990.

18. Shaw MK, Eramus DA. Schistosoma mansoni: structural damage and tegumental repair after in vivo treatment with praziquantel. Parasitology 94:243-254, 1987. 
19. Silva LM, Andrade ZA. Immunostimulation as adjuvant for the chemotherapy of experimental schistosomiasis. Revista do Instituto de Medicina Tropical de São Paulo 39:11-14,1997.

20. Wilson RA, Coulson PS, McHugh SM. A significant part of the "concomitant immunity" of mice to Schistosoma mansoni is the consequence of a leaky hepatic portal system, not immune killing. Parasite Immunology 6: 595-601, 1983.

21. Xiao SH, Catto BA, Webster LT Jr. Effect of praziquantel on different developmental stages of Schistosoma mansoni in vitro and in vivo. Journal of Infectious Diseases 151:1130-1137, 1985. 